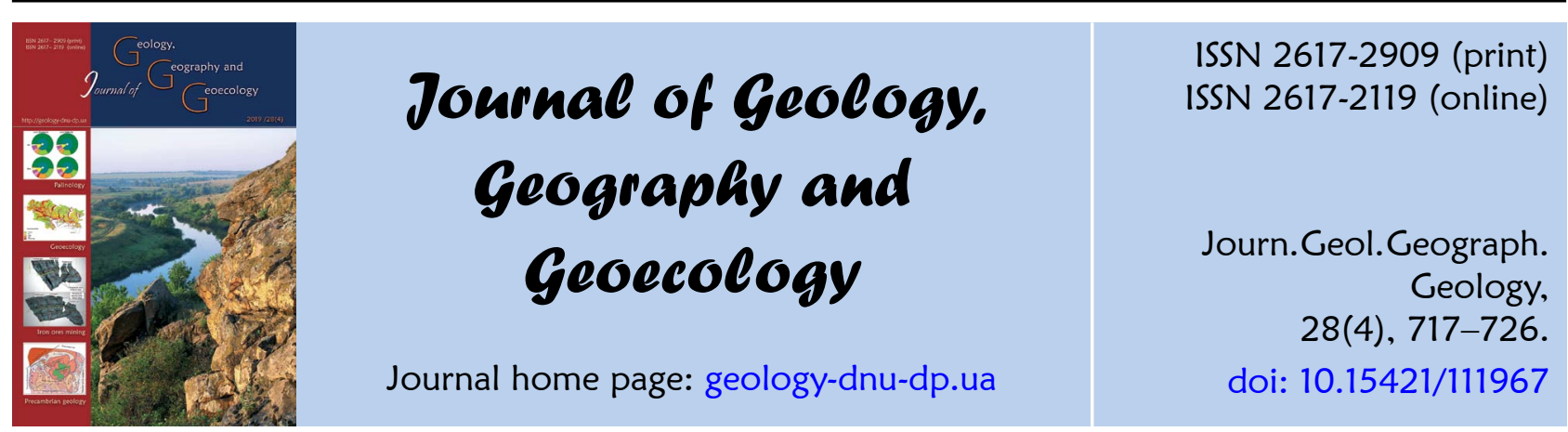

Irina V.Poruchynska, Volodymyr I. Poruchynsky, Andrey N. Slashchuk, Alla G. Potapova Journ. Geol. Geograph. Geoecology, 28(4), 717-726.

\title{
Functioning of the fuel-energy complex of Lviv Oblast in modern conditions
}

\author{
Irina V. Poruchynska, Volodymyr I. Poruchynsky, Andrey N. Slashchuk, Alla G. Potapova \\ Lesya Ukrainka East European National University, Lutsk, Ukraine, rinaporuchynska@gmail.com
}

Received: 10.05.2019

Received in revised form: 04.06 .2019

Accepted: 18.11.2019

Abstracts. The article provides a general characteristic and detailed analysis of the main spheres of the fuel and energy complex of Lviv Oblast. The paper proves the importance of development of the fuel and energy complex for the economy of Lviv Oblast and the welfare of its residents, for it fulfills the needs of the entire economic complex in fuel and energy, creates preconditions for development of various types of production, forms the basis for improvement of energy security of the region and country in general. The peculiarities of development of the fuel and energy complex were determined, the main of which are: large amount of coal extracted by mining, small-scale extraction of peat, absence of major electric power stations and high percentage of incoming electric energy from other regions. The paper gives a characterization of the energy balance in the Oblast, and also structure of reserves of coal mines and oil deposits. Areas promising for extraction of bituminous and brown coal, oil, gas, peat and other fuel resources were determined. The structure of consumption of fuel-energy resources by types of organic fuel was determined. Patterns of consumption of the main types of energy carriers in the region were distinguished. The structure of capacities of alternative energy resources in Lviv Oblast was determined. We determined the reasons for the low efficiency of use of natural resources and peculiarities and problems of the development of the energy sphere in the region, the main of which are the unsatisfactory technical condition of the objects of the fuel and energy complex, non-effective system of management in the sphere, absence of new sources of providing primary energy resources. We suggested recommendations on increasing the efficiency of functioning of the fuel and energy complex on the basis of use of non-traditional types of energy sources, i.e.: energy of sun, wind, biomass of solid fuel and others, which would allow natural and financial resources to be saved.

Keywords: fuel and energy complex, energy resources, energy sphere, energy balance, alternative energy.

\section{Функціонування галузей паливно-енергетичного комплексу Львівської області в сучас- них умовах}

\author{
I. В. Поручинська, В. І. Поручинський, А. М. Слащук, А.Г. Потапова
}

Східноєвропейський націіональний університет імені Лесі Українки, м. Луцьк, Украӥна, rinaporuchynska@gmail.com

\begin{abstract}
Анотація. У статті наведено загальну характеристику та проведено детальний аналіз основних галузей паливно-енергетичного комплексу Львівської області. Обгрунтовано важливість розвитку паливно-енергетичного комплексу для економіки Львівської області та добробуту її жителів, оскільки він забезпечує потреби всього господарського комплексу в паливі та енергії, створює передумови для розвитку різноманітних виробництв, формує базис для підвищення енергетичної безпеки регіону та держави в цілому. Визначено особливості розвитку паливно-енергетичного комплексу в області, основними 3 яких $є$ : значна частка видобутку вугілля шахтним способом, невеликі масштаби видобутку торфу, відсутність потужних електростанцій та висока частка надходження електроенергії з інших регіонів. Охарактеризовано енергетичний баланс області, а також структуру запасів вугільних шахт та нафтових родовищ. Виділено переспективні ділянки для видобутку кам’яного та бурого вугілля, нафти, газу, торфу та супітніх паливних ресурсів. 3'ясовано структуру споживання паливно-енергетичних ресурсів за видами органічного палива. Виділено закономірності споживання основних видів енергоносіїв у регіоні. Визначено структуру потужностей альтернативних джерел енергії у Львівській області. Висвітлено причини низької ефективності використання природних ресурсів та особливості і проблеми розвитку енергетичної галузі регіону, серед яких основними є незадовільний технічний стан об'єктів паливно-енергетичного комплексу, неефективна система управління галуззю, відсутність нових джерел постачання первинних енергоресурсів. Запропоновано рекомендації підвищення ефективності функціонування паливно-енергетичного комплексу на основі використання нетрадиційних видів джерел енергії, а саме: енергії сонця, вітру, біомаси твердого палива та інших, що дозволить зекономити природні та фінансові ресурси.
\end{abstract}


Ключові слова: паливно-енергетичний комплекс, енергетичні ресурси, енергетика, енергетичний баланс, альтернативна енергетика.

Relevance of the topic. The socio-economic development of Ukraine in general, and its regions in particular, is closely related to the level of the development of all structural units of the fuel and energy complex (FEC). Development of this sphere has a significant impact on the tempi of increase in the production and its scales. In modern economic conditions, fuel and energy are considered at the same time a resource and a factor of production. This conditions the relevance of the study of the peculiarities of the development of the fuel-energy complex of Ukraine at the regional level.

Analysis of studies and publications. The conditions and perspectives of development of the fuel and energy complex as an important component of the economy of the country have been studied in many research and scientific publications by both domestic and foreign authors. At the state level, the main aspects and perspectives of development of FEC in Ukraine and its regions are described in a number of legal acts, the Conception of State Energy policy of Ukraine for the period to 2020 (Kontseptsiia derzhavnoi enerhetychnoi polityky Ukrainy na period do $2020 \mathrm{roku}$ ), and the main directions of re-
Main material. The fuel and energy complex of Lviv Oblast is a component of the fuel and energy complex of Ukraine. Peculiarities of structural organization of the FEC in the Oblast are determined by the presence of two elements: fuel, which is the main, and the energy, which performs service functions in provision and distribution of energy. The structure of the FEC forms on the basis of its own fuel and energy resources (oil, free gas, associated gas, condensate, bituminous coal, methane of coal deposits, peat) which accounts for $37.8 \%$ of the entire mineral-raw material base of the Oblast.

Among the peculiarities of the FEC of Lviv Oblast we should distinguish the following: large share of extraction of coal in mines; insignificant scales of peat extraction; absence of major electric power stations and high percentage of incoming electric energy; impossibility of development of hydroenergetics; insignificant use of oil products imported to the Oblast.

Currently, energy balance in the Oblast forms on the basis of gas, bituminous coal, firewood for heating, peat and electric energy (Table 1). In Ukraine, share of Lviv Oblast in extraction of coal accounts for $2.6 \%$ of coal, $6.2 \%$ of raw oil, $3.4 \%$ of

Table 1. Energy balance in Lviv Oblast*

\begin{tabular}{|c|c|c|}
\hline Type of fuel & Consumption of energy resources & Production of energy resources \\
\hline Gas & $1,850.9 \mathrm{M} \mathrm{m}^{3}$ & $670.1 \mathrm{M} \mathrm{m}^{3}$ \\
\hline Coal & $1,264.0$ thou $\mathrm{T}$ & $1,150.1$ thou $\mathrm{T}$ \\
\hline Peat & No data & No data \\
\hline Electric energy & $4,577.0 \mathrm{M}$ of $\mathrm{kWh}$ & $3,067.5 \mathrm{M}$ of $\mathrm{kWh}$ \\
\hline Firewood & 201.6 thou $\mathrm{m}^{3}$ & 218.5 thou $\mathrm{m}^{3}$ \\
\hline Raw oil & 2.4 thou $\mathrm{T}$ & 141.2 thou $\mathrm{T}$ \\
\hline
\end{tabular}

Source: Mineralni resursy Ukrainy. Shchorichnyk (2018)

forms in the energy sector have been included in the Energy Strategy of Ukraine to 2035 (Kontseptsiia Enerhetychnoi stratehii Ukrainy na period do 2030 roku (proekt), 2014).

Notable specialists in studying the fuel and energy sphere are V. H. Burlaka, H. H. Burlaka, V. O. Vershynina, O. Vlasiuk, V. S. Kudlai, L. S. Seliverstova, Z. K. Sidnieva, O. M. Riabchyn, I. Chukaeva, A. K. Shydlovsky, R. V. Sherstiuk, Y. V. Yaskovets and others.

The objective of the study was determining modern tendencies in development of the main spheres of the fuel-energy complex in Lviv Oblast. natural gas. If for the first two types of fuel resources, an increase in the share is observed, the share of gas is seen to decrease.

The Oblast is self-sufficient in terms of peat, coal and firewood for heating. Its own extraction of gas and generation of electric energy fulfill $40 \%$ of needs in gas and $46 \%$ in electricity.

Within Lviv Oblast, the Chervonohrad coalindustrial region (Zabuzke, Mezhyrichia, Busk deposits) and South-Western coal-bearing area (Tiahliv and Liubelia deposits) of the Lviv-Volyn bituminous coal basin are located.

The Chervonohrad coal-industrial district 
concentrates around $80 \%$ of all balance reserves of coal, most operating mines and almost all coal fields prepared for further industrial development. Maximum coal-bearing is in the south part of the district in the Velykomostivska group of mines.

Currently, in the territory of the Oblast, six mines operate. Balance reserves of coal in the operating mines equals around $164 \mathrm{M} \mathrm{T}$. Most of them are
$400 \mathrm{~m})$, nitrogen-methane (400-500 $\mathrm{m})$ and methane (below $500 \mathrm{~m}$ ). Total resources of methane in the mines are estimated to be $10 \mathrm{~b} \mathrm{~m}^{3}$. Degassing works are performed in three mines. Extraction of coalbed methane requires conducting significant scientific studies, introduction of efficient technologies for survey and extraction from coal deposits.

Deposits of brown coal in Lviv Oblast are related

Table 2. Structure of reserves of coal mines in Lviv Oblast*

\begin{tabular}{|c|c|c|}
\hline \multirow{2}{*}{ Name of the mine } & \multicolumn{2}{|c|}{ Capacity, thou T } \\
\cline { 2 - 3 } & Projected & Determined productive capacity for 01.01.2018 \\
\hline Velykomostivska & 450 & 300 \\
\hline Mezhyrichanska & 750 & 300 \\
\hline Vidrodzhennia & 750 & 350 \\
\hline Lisova & 600 & 250 \\
\hline Stepova & 2400 & 500 \\
\hline Chervonohradska & 900 & 500 \\
\hline
\end{tabular}

Source: Mineralni resursy Ukrainy. Shchorichnyk (2018)

situated in the Stepova, Chervonohradska and Lisova mines, and the largest determined industrial capacities are located in the Stepova and Chervonohradska mines (Table 2).

An important factor of increase in the extraction of coal is combining maximum extraction of coal reserves and protection of deposits. For reducing waste of coal during extraction, which can reach 20$40 \%$, new highly efficient technologies of processing should be introduced. Also, a promising aspect is involvement of deep horizons.

The resource base of the coal basin allows creation of a powerful FEC which can provide the region with energy resources, and also contribute to the development of the economy of the entire country. A promising area is South-West district with coalbearing areas with discovered reserves of over 1,000 M T within its limits. Coal within this district is of highest quality, lowest ash and sulfur content and best property for enrichment. Also, within the Chervonohradsk geologic-industrial district, areas were prospected for constructing mines, reserves in which account for almost $200 \mathrm{M} \mathrm{T}$. Furthermore, there is a possibility of extracting up to $500 \mathrm{~b} \mathrm{~m}^{3}$ of coal-mine methane (Ofitsiinyi veb-portal Enerhetyka Ukrainy. Statystyka).

Prospects for further development of the LvivVolyn bituminous coal basin are related to presence of methane in the coal seams and coal-bearing rocks, as an additional fossil fuel. By component composition of gases within the basin, three gas zones are distinguished: methane-nitrogen (depth to to Neogene deposits. Five brown coal deposits have been explored - Rava-Ruske, Nesterivske (Zhovtnivske), Maherivske, Zolochivske and Yasenivske.

However, it should be noted that the technical equipment of enterprises in the region is outdated, by its technical and economical parameters it is quite inferior to the level of countries abroad and requires complete modernization. Technical re-equipment of the operating mines and construction of new ones in a short period would allow doubling of coal extraction in Lviv-Volyn basin, which can completely fulfill the needs in FEC in the Western region (LvivskoVolynskyi kamianovuhilnyi basin).

Lviv Oblast is one of nine regions in Ukraine, in which oil is extracted. Oil in the territory of the Oblast was found in 20 deposits with extractable industrial deposits of 216.4 M T, though it is extracted only in ten.

The structure of oil reserves in the deposits of Lviv Oblast is demonstrated in Table 3.

In terms of reserves, the biggest deposits are Boryslavske, Stynavske, Orliv-Ulychnianske, Orhovske, Semyhynivske and Starosambivske. 70-75\%, of oil reserves in the region have been used though potential resources in the region exist, of which only $30 \%$ are developed.

The main pipelines runs across the territory of the Oblast. Thus, from the north-east to the south west, the Oblast is crossed by the Druzhba pipeline which provides oil to Europe. The Odesa-Brody pipeline is not operated at full capacity. 
Table 3. Structure of oil reserves in deposits of Lviv Oblast, thou $\mathrm{T}^{*}$

\begin{tabular}{|c|c|c|c|c|c|}
\hline $\begin{array}{l}\text { Extracted since the } \\
\text { exploration started }\end{array}$ & Total & Balance & $\begin{array}{c}\text { Conditionally bal- } \\
\text { anced }\end{array}$ & Off-balance & $\begin{array}{c}\text { With undetermined } \\
\text { industrial value }\end{array}$ \\
\hline 44,980 & 245,936 & 22,813 & 0 & 185,103 & 38,026 \\
\hline & $100 \%$ & $9 \%$ & 0 & $75 \%$ & $16 \%$ \\
\hline
\end{tabular}

Source: Mineralni resursy Ukrainy. Shchorichnyk (2018); Ofitsiinyi sait Holovnoho upravlinnia statystyky u Lvivskii oblasti

By gas reserves Lviv Oblast is on the third position after Poltava and Kharkiv Oblasts. The main potential of Lviv Oblast was used in the 1950-60s. However, in the territory of the region, non-explored gas deposits remain, making the Oblast promising for development of gas extraction. Particularly, its territory has 64 deposits of natural gas, 37 of which are being developed. The extractive deposits account for $73.1 \mathrm{~b} \mathrm{~m}^{3}$. The territory of the Oblast is crossed by gas pipelines, the network of which is quite ramified and covers five gas-compressor and dozens of gasdividing stations.

In 2018, in Lviv Oblast, two new deposits of natural gas were discovered - in Drohobych and Zhydachiv district. Predicted reserves of each of these deposits equal around $1 \mathrm{~b} \mathrm{~m}^{3}$.

Gas-like fuel-energy fossil fuels include free gases and methane in gas deposits. In the territory of the Oblast, there are 36 deposits of free gas, extracted deposits of which account for $114.7 \mathrm{~b} \mathrm{~m}^{3}$, which is $8.4 \%$ of the total reserves in Ukraine. Out of them, three deposits, Haiivske, Bilche-Volynske, Hidnovytske, are the largest by the amounts of gas extraction (almost $5 \%$ of all Ukrainian reserves). In total, in the Oblast, 33 deposits of methane are being exploited. For the five deposits, industrial reserves of ethane, propane and butane are estimated. They are extracted in the Boryslavske and Zavadivske deposits.

The territory of the Oblast has 47 potential oilgas objects which are prepared for deep boring, in which potential resources of free gas are estimated at $37.527 \mathrm{~b} \mathrm{~m}^{3}$, and oil $-20.825 \mathrm{~b} \mathrm{t}$.

Over the recent years, the oil and gas industries in the Oblast have provided stable extraction, supply and transport of hydrocarbons both for export and to domestic consumers. During 2018, 11 new wells were put into operation. In addition, the natural decrease in extraction of gas in exhausted deposits which have been operated since the last century has been stopped.

Gas condensate is represented by nine deposits with reserves of 724 thou t. The largest deposits are Ivanykivske, Zaluzhanske and Haivske.

In the territory of Lviv Oblast the deposits of oil shales have been explored. By qualitative parameters, conditions of bedding and reserves, the following deposits have been distinguished ; Verhnie Synievydne, Boryslav, Shidnytsia. In the process of semi-cocking, out of them crude shale oil, aqueous distillate and fuel gas can be obtained. Artificial fuel obtained from oil shales is economically profitable during high oil prices.

Peat resources in Lviv Oblast have significant energy and agrotechnical potential. Peat can be used as a municipal-domestic local fuel and can be a source of raw material for other branches of th national economy.

In the territory of the Oblast, 74 deposits of peat are located, among which five are being periodically developed. By area, the largest industrial peat deposits are Stoianivske (4,138 ha), Solokiiske (3,881 ha), Radehivske (1,646 ha), Polonychna (1,566 ha) Lvivske (2,226 ha), Leshnivske (2,816 ha), Smilnenske (2,036 ha). Maximum thickness of peat deposits ranges 2.3$11.0 \mathrm{~m}$, average thickness -1.15 to $4.37 \mathrm{~m}$. Today, peat is extracted only in the Lopatynske and Stoianivske deposits for the needs of peat briquette plants.

General energy potential of peat in Lviv Oblast equals $690.6 \mathrm{M}$ of MWh. According to this parameter, the region is inferior to such Oblasts as Kyiv, Rivne, Volyn, and Chernihiv, though it significantly exceeds the energy potential of the rest of the oblasts (Table4).

Peat fuel granules, briquettes, and also sod peat can be used as solid fuel in industrial enterprises, for gas generators, heat-only boiling stations at plants, railway transport. Complex use of peat simultaneously for the needs of agriculture and industry is conditioned by large variety of its types even within one deposit (Atlas enerhetychnoho potentsialu vidnovliuvanykh ta netradytsiinykh dzherel enerhii Ukrainy, 2001). In perspective, peat can be used as fuel for thermal power stations, currently it is used as municipal-domestic fuel and as organic fuel for agriculture. On its basis soils are used for seedlings of vegetables, slabs and blocks for thermal and sound insulation are pressed to be used in construction.

Electric energy in the Oblast is powered by the Dobrotiv Thermal Electric Power Station, which generates half of the electric energy the Oblast requires, Novoshychi and Yavora Hydroelectric Power 
Table 4. Energy potential of peat in Oblasts of Ukraine

\begin{tabular}{|c|c|c|}
\hline Oblast & $\begin{array}{c}\text { Total energy potential of peat, } M \text { of } \\
\text { MWh }\end{array}$ & $\begin{array}{c}\text { Economically practical potential, } M \text { of } \\
M W h\end{array}$ \\
\hline Vinnytsia & 136.4 & 34.6 \\
\hline Volyn & $1,378.1$ & 761.8 \\
\hline Dnipropetrovsk & 0.25 & - \\
\hline Zhytomyr & 290.5 & 159.2 \\
\hline Zakarpattia & 0.2 & - \\
\hline Zaporizhia & 1.08 & - \\
\hline Ivano-Frankivsk & 45.2 & 17.19 \\
\hline Kyiv & 716.5 & 146.5 \\
\hline Kirovohrad & 8.7 & - \\
\hline Lviv & 690.6 & 244.1 \\
\hline Mykolaiv & 1.26 & - \\
\hline Poltava & 364.3 & 143 \\
\hline Rivne & $1,176.2$ & 575.3 \\
\hline Sumy & 331.0 & 575.3 \\
\hline Ternopil & 384.3 & 114.8 \\
\hline Kharkiv & 15.7 & - \\
\hline Kherson & 11.3 & 7.96 \\
\hline Khemelnytsk & 236.6 & 99.04 \\
\hline Cherkasy & 191.6 & 79.7 \\
\hline Chernihiv & 818.5 & 356 \\
\hline Total & $6,801.0$ & 2,941 \\
\hline
\end{tabular}

Source: Atlas enerhetychnoho potentsialu vidnovliuvanykh ta netradytsiinykh dzherel enerhii Ukrainy (2001)

Stations. Also, combined heat and power plant Lviv CHP-1 and Lviv CHP North, Novoiavorivsk CHP operate.

Production of electric energy provides around $25 \%$ of the total volume of the realized industrial production of the Oblast. The dynamics of the production of electric energy in the Oblast, represented in Fig. 1, up to 2017, indicate a tendency towards increase, though over the last year its production fell by $10 \%$.
Analysis of the structure of consumption of fuel and energy resources in 2019 by types of organic fuel shows that the share of natural gas accounts for $56 \%$, oil and oil products $-21.4 \%$, coal $-19 \%$, other types of fuel $-3.6 \%$ (including firewood for heating $1 \%$ ) (Fig. 2).

Over the recent period, consumption of firewood has increased due to the rise in prices of energy providers. Firewood is used for heating homes,

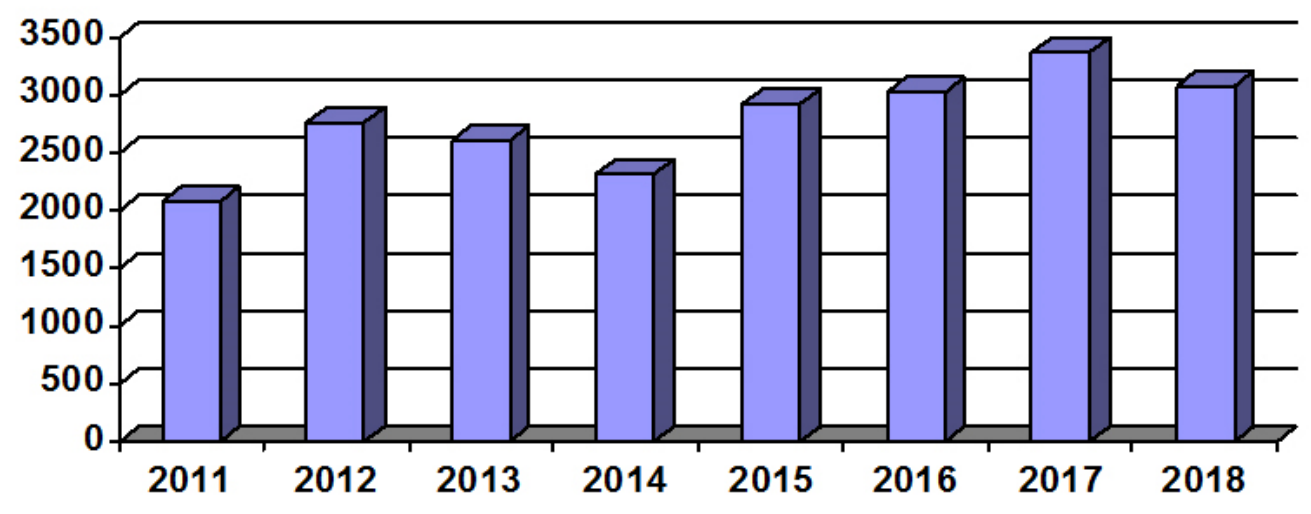

Electric energy, M kWh

Fig. 1. Generation of electric energy in Lviv Oblast in 2011-2018.

Source: Ofitsiinyi sait Holovnoho upravlinnia statystyky u Lvivskii oblasti 

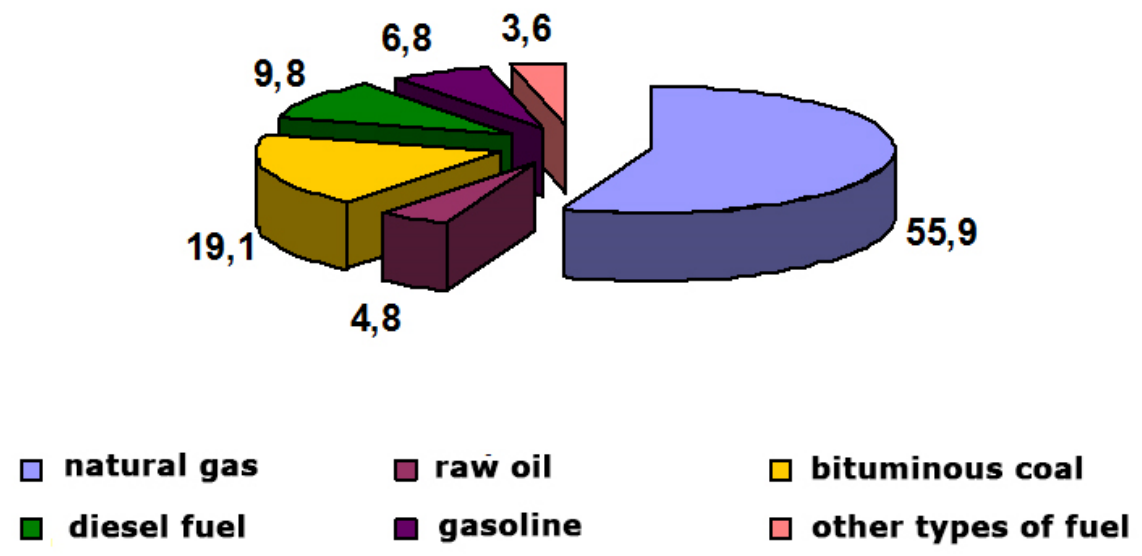

Fig. 2. Structure of use of fuel in Lviv Oblast, \%

Source: Ofitsiinyi sait Holovnoho upravlinnia statystyky u Lvivskii oblasti

especially in rural areas. As fuel, wastes of the logging, sawing and wood-working spheres are used.

The largest amount of fuel-energy resources is used by the local population, and the most powerconsuming spheres are economic activities involved in generation and distribution of electric energy, gas, water, and also spheres of processing industries and transport and communication.

In general, in the region, a certain pattern in consumption of the main types of energy sources is seen: coal, natural gas and firewood for heating are used the most by industrial enterprises, institutions of state management and defense; at the same time, gasoline and diesel fuel are consumed mostly by transport, communication services, in agriculture and forestry (Fig. 3). (Ofitsiinyi sait Holovnoho upravlinnia statystyky u Lvivskii oblasti).

By amount of use of electric resources, the leaders are city of Lviv (43.2\%) and Kamianko-Byzky district $(23.5 \%)$. A high amount of consumption of

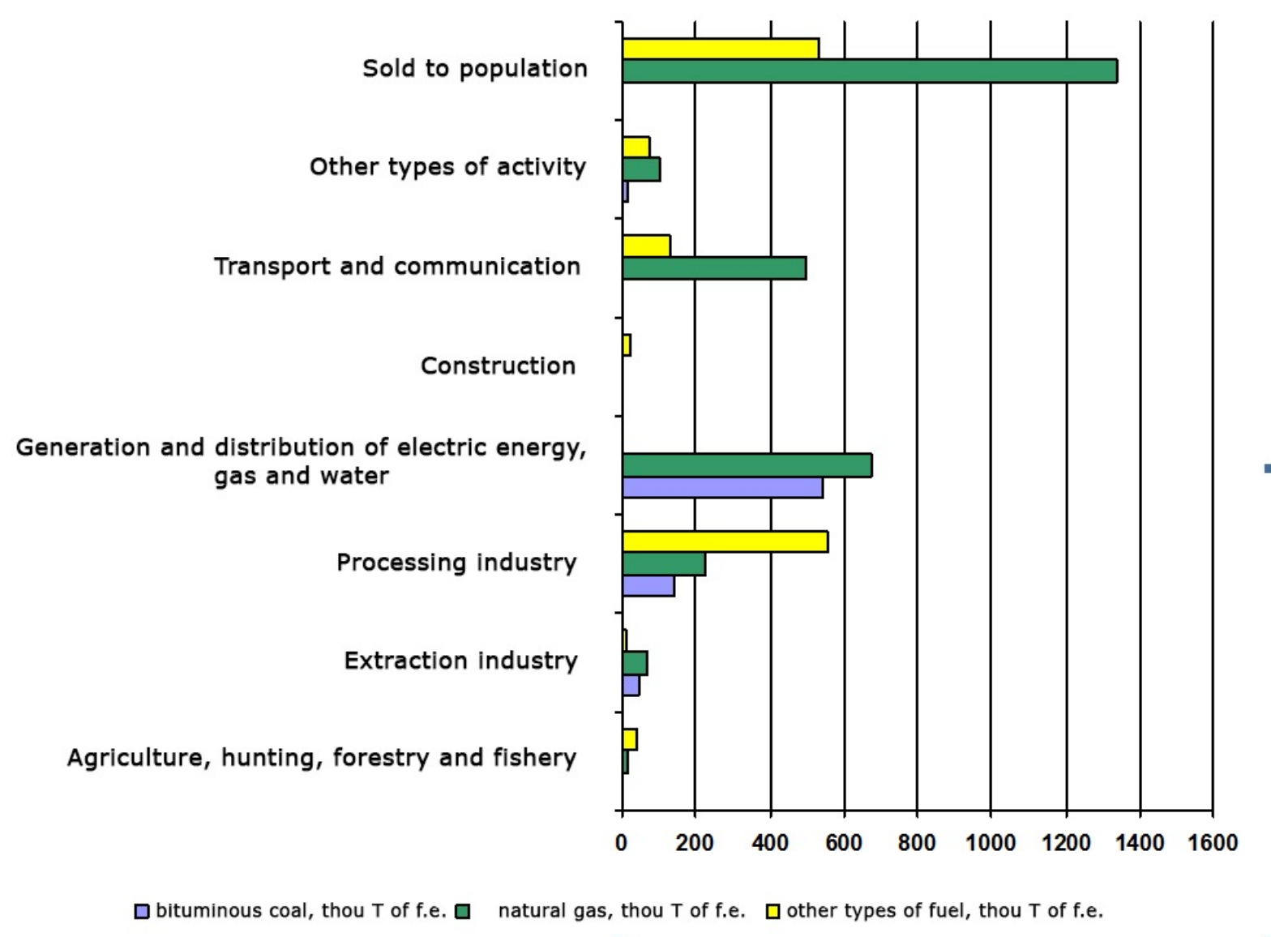

Fig. 3. Structure of amounts of consumption of fuel-energy resources in Lviv Oblast Source: Ofitsiinyi sait Holovnoho upravlinnia statystyky u Lvivskii oblasti 
resources is seen also in Radekhiv, Sokal, Yavoriv, Mykolaiv districts, and also in the cities Novyi Rozdil, Drohobych and Chervonohrad (4.5\%, 3.1\% 2.8 $\% 2.3 \%, 3.2 \%, 2.6 \%$ and $2.1 \%$ respectively).

The territorial peculiarities of consumption of different types of fuel-energy resources in Lviv Oblast should also be mentioned. Particularly, bituminous coal is used the most by enterprises and organizations in Kamianka-Buzka, Mykolaiv, Sokal, Zhydachiv administrative districts, and the city of Chervonohrad. Natural gas is used the most in the cities Lviv and Novyi Rozdil, and also Radekhiv and Yavoriv districts.

A characteristic feature of the modern energy industry is development of technologies on the basis of non-traditional and renewable sources of energy, the use of which contributes to solving problems of effective provision of energy, and also problems of an ecological, economic and social character in Ukraine and its regions.

Today, Lviv Oblast is considered one of the most active regions of Ukraine in terms of development and introduction of alternative energy. According to the results of the assessment of energetic potential of renewable resources of energy, the Oblast has a suf- dicator in Ukraine, which is the highest among the Oblasts of the Carpathian Region. The structure of theoretically achievable energetic potential of renewables in the Oblast equals 299.4 thou $\mathrm{T}$ of f.e./year (Table 5).

The energy of biomass is understood as wastes of forestry and agricultural plants, energetic plants (maybe better energy crops), and the environmental energy - geothermal energy and energy of drainage water.

Lviv Oblast is second in Ukraine in the number of small mountain rivers and the possibility of constructing hydroelectric stations on them. Their potential is estimated in $500 \mathrm{M} \mathrm{kWh}$ per a year, that is $10 \%$ of all consumption of electric energy in the Oblast. The main share of the energy belongs to the rivers Dnister, Stryi, Opir and their tributaries. Small hydroelectric stations could become an important source of providing energy in the Oblast, especially in its mountain regions, to which the largest share of the energy potential of the small rivers belongs.

For the development of the biomass in Lviv Oblast, there is significant resource potential in wastes from wood, agriculture, and also free areas of land for planting energy plants, particularly energetic willow,

Table 5. Structure of potential of renewable in Lviv Oblast

\begin{tabular}{|l|c|}
\hline \multicolumn{1}{|c|}{ Type of energy } & Energy potential, thou of T of fuel equivalent \\
\hline Solar energy & 40.6 \\
\hline Wind Energy & 74.6 \\
\hline Small-scale hydro energy & 8.9 \\
\hline Environmental energy & 71.7 \\
\hline Biomass energy & 98.4 \\
\hline Biogas energy & 5.2 \\
\hline Total & 299.4 \\
\hline
\end{tabular}

Source: Atlas enerhetychnoho potentsialu vidnovliuvanykh ta netradytsiinykh dzherel enerhii Ukrainy (2001)

ficient natural potential of renewable sources for production of thermal and electric energy in industrial amounts (Syrotiuk, 2014).

Taking into account the rather high parameters of potential of energy of wind, small rivers and biomass in the Oblast, there is a possibility of replacing organic fuel with energy from renewable sources practically by $50 \%$, and some districts, in perspective, can become energy-independent due to local renewables (Netradytsiini ta vidnovliuvani dzherela enerhii v Ukraini u svitli novykh yevropeiskykh initsiatyv, 2013).

Total technically achievable potential of renewables in Lviv Oblast accounts for 4.27 M T of fuel equivalent (f.e.)/year, measuring $4.3 \%$ of the total in- energetic poplar, silvergrass, etc.

The amount of forest wood wastes which can be used for energetic purposes equals around $30-40 \%$ of the amounts of lumbering. The largest amount of sawdust and firewood is provided by Drohobych, Zhovkinsky, Skole, Staryi Sambir, Turka districts. Wood wastes are supplied to special enterprises which produce pellets in industrial amounts, though they can be processed directly on the spot.

Among the wastes of agriculture, initial wastes are distinguished - those which remain in the fields as byproducts after harvest of initial agricultural crops. They include straw of cereals and rapeseed, stems of sunflower and maize. Secondary wastes include beet pulp of sugar beet, shells of sunflower, nut shell 
and other types of biomass of similar type, manure - organic substance used as organic fertilizer in agriculture. Wastes of livestock, manure, can be used as organic substance in agriculture.

Initial wastes of agriculture are potentially important for those administrative districts of Lviv Oblast, which have large areas with cereal crops Sokal, Zolochiv, Zhydachiv, Radekhiv and Brody. Secondary wastes of agriculture are most often concentrated in processing enterprises, where it is practical to use them for their own energetic needs.

The energy potential of biomass from wastes of livestock in the Oblast is estimated as high and economically practical for use, though it is closely associated with number of animals. Highest populations of cattle are located in Brody, Zhydachiv, Sokal and Sambir districts, of swine - in Stryisky, Busk, Sambir and Sokal, poultry - Pustomyty, Sambir and Zhydachiv. On average, around $665 \mathrm{M}$ $\mathrm{m}^{3}$ of biogas a year can be produced from livestock biomass, allowing replacement of almost 600 thou of conventional fuel.

If considering the existing structure, over half of it is the capacities of wind energy, less significant are the capacities of bioenergy and solar energy (Fig.4). tant complex of solar electric stations in the territory of Western Ukraine.

Potential of geothermal energy of Lviv Oblast equals around $7.0 \%$ f the total parameter in Ukraine. Particularly, in Yavoriv and Mostyska district, the deposit of geothermal water of $95-130{ }^{\circ} \mathrm{C}$ temperature has been explored; the water is embedded at the depth of $3 \mathrm{~km}$, creating favourable conditions for building a combined heat and power plant. Also, abandoned oil, gas and oil-gas wells could be used as sources of geothermal energy.

As for wind energy, the highland territories of Yavoriv, Mostyska and Zolochiv districts are considered promising. The promising plans for Lviv Oblast include construction of wind energy stations of general power of 400MWT. Electric stations Stary Sambir-2 and Sokalsky Wind Park are planned to be put into operation.

Also, in Lviv Oblast, energy of the environment can be used. It can be used in two ways. The first is related to the extraction of energy from natural flow of thermal groundwater to the Earth's surface or from corresponding geothermal wells. For this purpose, for extracting energy, special geothermal stations should be built for use of thermal energy by consum-

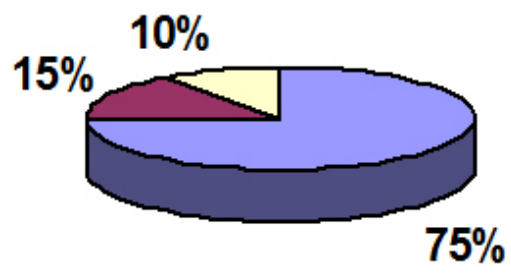

\section{$\square$ wind energy $\square$ bioenergy $\square$ solar energy}

Fig. 4. Structure of capacities of alternative sources of energy in Lviv Oblast

Source: Netradytsiini ta vidnovliuvani dzherela enerhii v Ukraini u svitli novykh yevropeiskykh initsiatyv

Over the last few years, all these branches showed notable increase and increase is predicted again in the next years.

Despite the fact that the territory of Lviv Oblast, compared to other regions of Ukraine, has a small level of energy of solar flow, use of solar energy in the region has been started and further development is planned. Particularly, in 2017, four solar electric power stations were put into operation: Ozerna, Boryslavska Solar Electric Station, Energetic fields of Solar Power Stations Ternovytsia 2 and 4, Leo-SolarEnergy, and in 2018 in Yavoriv District, the first stage of development of the solar energy station Yavoriv-1 was opened, which is a component of the most impor- ers in close proximity to geothermal sources. Today, in the Oblast, there are no conditions for development of thermal groundwater, therefore their energetic resource is not currently being considered (Kudlai, V., Seliverstova, L., 2013.).

The other way is related to use of thermal pumps for air-surface or well extraction of energy from soil and atmosphere. Thermal pumps are mostly used for heating individual buildings, hotels, kindergartens, etc. Particularly, in the cities of Drohobych and RavaRuska, geothermal thermal pumps have been installed for heating kindergartens, reducing costs of heating and supply of hot water by three times.

Despite its considerable natural potential, in Lviv 
Oblast, renewable energy is being developed at low tempi and the share of the used potential of renewables is insignificant. Therefore, $5.0 \%$ energy of biomass, $2.1 \%$ of sun, $1.1 \%$ of wind energy, 0.5 of energy of small rivers, and less than $0.1 \%$ of geothermal energy are used.

Conclusions. In the territory of Lviv Oblast, deposits of practically all types of oil-energy and fossil fuels are located - bituminous coal, natural gas, oil, peat. Reserves of coal in mines in operation account for around $170 \mathrm{MT}$. Furthermore, promising objects are the South-West and Chervonohrad geological-industrial districts, within which, areas for constructing mines were found with significant deposits. Also, scientific developments have confirmed the presence of large deposits of oil and natural gas at great depths.

In general, subsurface of the Oblast is sufficient for balanced development of industry and agriculture and can fulfill the needs of the Oblast for mineral raw materials. However, there is a number of disadvantages which significantly reduce the efficiency of use of the subsurface, failing to provide the protection required, causing discrepancies between the use of subsurface and protection of the natural environment.

Also, Lviv Oblast has a high natural potential in renewable sources of energy. In particular, the region has significant perspectives for industrial development of bioenergetics, wind and hydroenergy. Wind-energy potential first of all can be practically exploited in highland areas for the potential of these areas is one of the highest in Ukraine. A significantly promising sphere is bioenergetics, because total energy potential of biomass in the Oblast is over two times higher than the amounts of consumption of natural gas. For contributing to the development of bioenergy, enterprises for processing wood and organic wastes should be created. The region has significant potential for growing energy plants (willow, poplar, silvergrass) and their use for production of fuel. The region has high potential for small hydroenergy plants. However, for construction of new electric stations, not only should the features of rivers and surrounding territory be taken into account, but also new technologies for preserving species diversity and populations of river fish must be used.

Renewable energy can become one of the main directions of economical development of Lviv Oblast. Particularly the development of renewable energy in the region must be based on strategic planning with consideration of the total of factors of regional and local level.

\section{References}

Atlas enerhetychnoho potentsialu vidnovliuvanykh ta netradytsiinykh dzherel enerhii Ukrainy [Atlas of the energy potential of renewable and nontraditional energy sources of Ukraine] Retrieved from http://www.intelcenter.com.ua/rus/library/ atlas alten_UA.htm (in Ukrainian)

Barannik O. Okremi aspekty otsinky rivnia enerhetychnoi bezpeky rehioniv Ukrainy [Some aspects of assessing the level of energy security in the regions of Ukraine]. Retrieved from www.niss. gov.ua/.../energobezpeca-f5475.pdf

Chychyna, O., 2015. Stan ta perspektyvy rozvytku palyvno-enerhetychnoho kompleksu Ukrainy $\mathrm{v}$ umovakh hlobalizatsii [The state and prospects of the development of the fuel and energy complex of Ukraine in the conditions of globalization]. Young Scientist. 2 (17), 130-133. (in Ukrainian).

Chukaieva, I., 2004. Formuvannia efektyvnykh proportsii palyvno-enerhetychnoho balansu na perspektyvu yak baza enerhetychnoi stratehii Ukrainy [Formation of effective proportions of fuel and energy balance for the future as the basis of the energy strategy of Ukraine]. The law is right. 1, 97-101. (in Ukrainian).

European Economy. Member State's Energy Dependence: An Indicator-Based Assessment Retrieved from http://ec.europa.eu/economy finance/ publications/occasional_paper/2014/pdf/ocp196 en.pd

Evans, J. International Handbook on the Economics of Energy [Text]. J. Evans, C. Hunt. - Cheltenhem: Edward Elgar Publishing Limited, 2015. - 831 p.

Iaskovets Yu. V. Rozvytok palyvno-enerhetychnoho kompleksu Ukrainy $\mathrm{v}$ umovakh hlobalizatsii [Development of fuel and energy complex of Ukraine in the conditions of globalization] Retrieved from http://archive.nbuv.gov.ua/portal/ soc gum $/ \mathrm{knp} / 2010196 \quad 1 / \mathrm{knp} 236-240 . \mathrm{pdf}$

Kontseptsiia derzhavnoi enerhetychnoi polityky Ukrainy na period do 2020 roku [Concept of state energy policy of Ukraine for the period till 2020]. National Security and Defense Retrieved from http://www.uceps.org/ukr/files/category_journal/ NSD14_ukr.pdf

Kontseptsiia Enerhetychnoi stratehii Ukrainy na period do 2030 roku (proekt) [Concept of the Energy Strategy of Ukraine for the period up to 2030 (project)]. Kiev (in Ukrainian).

Kudlai, V., Seliverstova, L., 2013. Analiz efektyvnosti vykorystannia enerhetychnykh resursiv [Analysis of efficiency of use of energy resources]. KNUTD Bulletin. 6, 49-46 (in Ukrainian).

Kurmaiev P. Innovative and replenishment approach to regional economy management. P. Kurmaiev. European Researcher. - 2013. - №1. - P. 28-31. 
Kurmaiev P. Actual problems of renewable energe's usage. P. Kurmaiev, V. Rybchak. Development of Regions in Knowledge Economy. - Warsaw: Warsaw University of Life Sciences Publishing, 2014. - P. 47-53.

Lvivsko-Volynskyi kamianovuhilnyi basein - [Lviv-Volyn Carboniferous Pool] - Retrieved from https:// dt.ua/energy market/lvivsko-volinskiy-vugilniybaseyn-ne-vse-tak-gnityuche-.html (in Ukrainian)

Messner S, Schrattenholzer L. MESSAGEMACRO: linking an energy supply model with a macroeconomic module and solving it iteratively. Energy. -2000. -\#25. - P. 267-282.

Mineralni resursy Ukrainy. Shchorichnyk. [Mineral Resources of Ukraine. Yearbook].- 2017. Kiev (in Ukrainian).

Muradova O. Suchasnyi stan rozvytku palyvnoenerhetychnoho kompleksu Ukrainy - [The current state of development of the fuel and energy complex of Ukraine] Retrieved from http://archive.nbuv.gov.ua/portal/soc gum/Dtr ep/2011_6 (in Ukrainian)

Netradytsiini ta vidnovliuvani dzherela enerhii v Ukraini u svitli novykh yevropeiskykh initsiatyv - [Nontraditional and renewable energy sources in Ukraine in the light of new European initiatives]
Retrieved from http://old.niss.gov.ua/monitor/ november08/2.htm (in Ukrainian)

Ofitsiinyi sait Holovnoho upravlinnia statystyky u Lvivskii oblasti - [Official site of the Main Department of Statistics in Lviv Oblast] - Retrieved from www. lv.ukrstat.gow.ua (in Ukrainian)

Ofitsiinyi veb-sait Derzhavnoi sluzhby statystyky Ukrainy [Official website of the State Statistics Service of Ukraine] Retrieved from http://www.ukrstat.gov. $\underline{\text { ua// (in Ukrainian) }}$

Ofitsiinyi veb-portal Enerhetyka Ukrainy. Statystyka [Official web-portal Energy of Ukraine. Statistics]. Retrieved from http://uaenergy.com. ua/select/section/statistics/ (in Ukrainian)

Syrotiuk, S., 2014. Perspektyvy vidnovliuvanoi enerhetyky $\mathrm{V}$ enerhobalansi Lvivshchyny [Prospects for renewable energy in the energy balance of Lviv region]. Renewable energy in Lviv region - opportunities for business and development of the territory, 21. (in Ukrainian).

Vershynina, V., 2013. Stan ta zahalna otsinka rozvytku palyvno-enerhetychnoho kompleksu Ukrainy [Status and overall assessment of the development of the fuel and energy complex of Ukraine]. Development management. 22 (162), 127-129 (in Ukrainian). 